\title{
Émile Verhaeren, Correspondance générale II, Rilke et Dehmel (1905-1925)
}

\section{Angélique Gigan}

\section{Q OpenEdition}

1 Journals

\section{Édition électronique}

URL : https://journals.openedition.org/studifrancesi/3195

DOI : 10.4000/studifrancesi.3195

ISSN : 2421-5856

Éditeur

Rosenberg \& Sellier

\section{Édition imprimée}

Date de publication : 1 juillet 2013

Pagination : 483

ISSN : 0039-2944

\section{Référence électronique}

Angélique Gigan, «Émile Verhaeren, Correspondance générale II, Rilke et Dehmel (1905-1925) 》, Studi

Francesi [En ligne], 170 (LVII | II) | 2013, mis en ligne le 30 novembre 2015, consulté le 02 février 2023. URL : http://journals.openedition.org/studifrancesi/3195; DOI : https://doi.org/10.4000/studifrancesi. 3195

Ce document a été généré automatiquement le 2 février 2023.

\section{cc) (†) $\ominus$}

Creative Commons - Attribution - Pas d'Utilisation Commerciale - Pas de Modification 4.0 International - CC BY-NC-ND 4.0

https://creativecommons.org/licenses/by-nc-nd/4.0/ 


\title{
Émile Verhaeren, Correspondance générale II, Rilke et Dehmel (1905-1925)
}

\author{
Angélique Gigan
}

\section{RÉFÉRENCE}

ÉMILE VERHAEREN, Correspondance générale II, Rilke et Dehmel (1905-1925), édition présentée, établie et annotée par Fabrice van de KERCKHOVE, Bruxelles, A.M.L. Éditions, 2012 («Archives du futur»), pp. 237.

1 Second volume consacré à la correspondance d'Émile Verhaeren, l'édition établie par Fabrice van de Kerckhove est bien plus qu'une présentation des échanges épistolaires que le poète belge a entretenus avec Dehmel et Rilke entre 1905 et 1925. Les nombreuses annotations, la très éclairante postface et la chronologie synoptique sont en effet des outils essentiels qui apportent un éclairage nouveau sur le contexte dans lequel cette correspondance s'est mise en place et sur les liens qui unissaient Verhaeren à ces deux poètes, dont l'admiration était réciproque. L'intégration judicieuse de la Lettre du jeune ouvrier de Rilke, lettre fictive destinée à Verhaeren et rédigée en février 1922, soit six années après la mort du poète belge, et qui fait l'objet ici d'une nouvelle traduction par F. van de Kerckhove lui-même, souligne non seulement l'influence de Verhaeren sur Rilke, mais aussi le rôle du modèle de la lettre comme moyen de poursuivre une relation spirituelle avec celui qui incarnait à ses yeux une figure paternelle.

2 Cette correspondance met en relief la nature des relations qui unissaient Verhaeren à ces deux poètes germaniques: tandis qu'avec Richard Dehmel, les rapports sont davantage d'ordre politique, notamment avec le rêve commun d'une «Europe supranationaliste» créée par les «Ingénieurs des Forces tumultueuses», le liens avec Rainer Maria Rilke sont davantage amicaux. La rupture définitive de Verhaeren avec les intellectuels allemands à la suite de l'avènement de la Première Guerre mondiale met fin à ces relations épistolaires, en même temps qu'elle anéantit son rêve d'universalité 
européenne. Ce n'est qu'en 1925 que Rilke apprend de la veuve de Verhaeren qu'il était le seul pour qui le poète belge avait conservé son amitié.

3 Outre le contexte intellectuel et politique, cette correspondance met en lumière le dépassement de la barrière linguistique: si les lettres sont en effet rédigées en français, les ouvrages que Verhaeren recevait de ses correspondants étaient écrits en allemand, langue qu'il maîtrisait très peu. Ces dons symbolisent néanmoins le respect et l'enthousiasme mutuels qu'ils se portaient. Car, indépendamment des événements historiques, la correspondance de Verhaeren avec Dehmel et Rilke révèle chez chacun d'eux la volonté, par la poésie, de transformer l'homme pour lui offrir un monde nouveau, à partir des valeurs qui sont celles d'intellectuels européens du début $d u \mathrm{xx}^{\mathrm{e}}$ siècle. 